\title{
"What Goes Up Must Come Down": Exploring the Harms Experienced By a Group of Heavy Ecstasy Users in Melbourne and Discussing the Implications for Harm Reduction
}

\author{
Amy Pennay ${ }^{*}, 1,2$ \\ ${ }^{I}$ National Drug Research Institute, Curtin University of Technology, Australia \\ ${ }^{2}$ Turning Point Alcohol and Drug Centre, Australia
}

Keywords: Ecstasy, harms, mental health, cognition, harm reduction.

\section{INTRODUCTION}

This paper presents findings from an ethnographic study of a group of young recreational drug users in Melbourne. This group of young recreational drug users derived many benefits from their ecstasy and other drug use, including sociability and pleasure; however, they also experienced a range of harms from their frequent drug use. This paper discusses these harms and then reflects on the implications for harm reduction policy.

\section{METHODS}

The data reported in this paper were collected over 14 months. During this period, ethnographic research $[1,2]$ was conducted among a social network of approximately 80 young people who regularly consumed ecstasy. Data collection involved two components: fieldwork and in-depth interviews. Fieldwork was conducted in a variety of restaurants, pubs, bars, nightclubs, music festivals and private homes. Field notes were made following episodes of fieldwork. In-depth interviews were conducted with 25 core group members. Field notes and interview transcripts were stored and analysed using NVivo 7. The qualitative analysis was inductive, with emergent themes and theoretical issues reassessed as fieldwork progressed, and used to guide the collection of further data in an 'ethnographic cycle' [3]. Narratives were analysed using thematic and content analysis. The ethnographic analysis was informed by a review of epidemiological and qualitative research on alcohol and party drug use, as well as relevant aspects of the anthropological, sociological and youth studies literature.

\section{RESULTS}

This group of 'heavy' ecstasy users pursued ecstasy intoxication in a way that may be described by outsiders as 'excessive' or 'carnal'. Females estimated that they averaged around 2.7 ecstasy pills per session, while males averaged around 5.3 pills per session; however occasions where upwards of 10 ecstasy tablets were consumed were not uncommon. One of the themes that arose during fieldwork

*Address correspondence to this author at the Turning Point Alcohol and Drug Centre, Australia; Tel: +61 38413 8460; Fax: 61394163420 ;

E-mails: amyp@turningpoint.org.au, amy.pennay@postgrad.curtin.edu.au was that ecstasy was associated with a number of harms. The primary harms experienced by this group included "the sads" (mental health-related harms), being "scattered" (cognitiverelated harms which negatively impacted employment), financial loss (lack of savings) and stigma-related social problems (loss of friendship with non-drug users).

\section{DISCUSSION}

These harms, although somewhat recognised in the broader literature [4-7], are not typically identified in popular harm reduction messages. Harm reduction messages that focus on risk of overdose and blood borne virus transmission, although potentially relevant to injecting drug users, are likely to be meaningless to recreational drug users. So what are some of the more relevant and realistic harm reduction implications for a group of young people who explicitly reject 'controlled' or 'moderate' drug use? And how should harm reduction be framed for those who articulate its ethos but pursue pleasure in practice?

\section{CONCLUSION}

It is time for harm reduction to deal with pleasure if it is going to bear any correlation with the real experiences of recreational drug users [8-10]. Where 'controlled' drug use is represented as self-evidently good, there is a risk of failing to grasp the dynamics of drug use, as well as some of the reasons why harm reduction measures are not always adopted by drug users. At the very least, drug campaigns, and the media in general, could avoid representing young party drug users as incompetent, disordered citizens, for example, in graphic images of young people experiencing ecstasy overdose. Messages that recognise drug user subjects as evincing competence, responsibility and a desire to reduce harm, whilst simultaneously pursuing pleasure, may be experienced as empowering by young drug users, thus enabling them to deal with drug-related problems more effectively, and create new forms of drug user identity and ethics.

\section{REFERENCES}

[1] Hammersley M, Atkinson P. Ethnography: principles in practice. $3^{\text {rd }}$ ed. Abingdon: Routledge 2007.

[2] Pearson G. Normal drug use: ethnographic fieldwork among an adult network of recreational drug users in inner London. Subst Use Misuse 2001; 36: 167-200. 
[3] Spradley J. Participant observation. New York: Holt, Rinehart and Winston 1980.

[4] Lee N. Risks associated with psychostimulant use. Models of intervention and care for psychostimulant users. Monograph series number 51. In: Baker A, Lee N, Jenner L, Eds. Canberra: Commonwealth of Australia 2004.

[5] Maxwell, J. Party drugs: properties, prevalence, patterns, and problems. Subst Use Misuse 2005; 40: 1203-40.

[6] Carlson RG, McCaughan JA, Russel SF, et al. Perceived adverse consequences associated with MDMA/Ecstasy use among young polydrug users in Ohio: implications for intervention. Int J Drug Policy 2004; 15: 265-74.
[7] White B, Degenhardt L, Courtney B, et al. Risk and benefit perceptions of party drug use. Addict Behav 2006; 31: 137-42.

[8] Duff C. Drug use as a 'practice of the self': is there any place for an ethics of moderation in contemporary drug policy? Int $\mathrm{J}$ Drug Policy 2004, 15: 385-93.

[9] Boys A, Marsden J, Griffiths P, Fountain J, Stillwell G, Strang J. Substance use among young people: the relationship between perceived functions and intentions. Addiction 1999; 94: 1043-50.

[10] Moore D, Fraser S. Putting at risk what we know: reflecting on the drug-using subject in harm reduction and its political implications. Soc Sci Med 2006; 62: 3035-47.

(C) Amy Pennay; Licensee Bentham Open.

This is an open access article licensed under the terms of the Creative Commons Attribution Non-Commercial License (http://creativecommons.org/licenses/ by-nc/3.0/) which permits unrestricted, non-commercial use, distribution and reproduction in any medium, provided the work is properly cited. 